\title{
Patricia Martínez-Álvarez
}

Teachers College, Columbia University, United States

María Paula Ghiso

Teachers College, Columbia University, United States

Gerald Campano

University of Pennsylvania, United States

\section{ENGAGING DOUBLE BINDS FOR CRITICAL INQUIRY WITH FIRST-GRADE LATINA/O EMERGENT BILINGUALS}

\begin{abstract}
Summary. This two-year predominantly qualitative study engaged 103 bilingual first graders in a literacy curriculum that sought to blend in- and out-of-school experiences, with particular emphasis on using photography and other multimodal texts as semiotic resources. Drawing on critical pedagogy and cultural historical activity theory, we supported students in interrogating epistemologies resulting from dominant hegemonic perspectives. As part of the curricular invitations, children photographed their everyday family and community experiences, and employed these images for oral storytelling and multimodal composing. Data sources analyzed for this article include children's audiorecorded dialogic small group discussions and their multimodal texts. We analyzed the data thematically and discursively, identifying patterns across children's engagements with their photos in the literacy curriculum. We found that young emergent bilinguals enacted agency by bringing often-silenced social issues and community knowledge to the forefront of school-based learning. We examine turning points in the dialogic discussions that helped create openings to voice topics often excluded from classroom contexts, and argue that such pedagogical spaces can support children in de-stabilizing historically rooted double binds that reinforce cultures of silence. Through illustrative examples of students' talk and texts, we explore how a specific focus on blending oral storytelling-stimulated dialogue with technology can become a platform for critical inquiry that engages, rather than suppresses, the double binds children experience by virtue of their immigration histories and cultural and linguistic identities.
\end{abstract}

Keywords: bilingual education; critical literacy; critical pedagogy; educational technology; elementary education; multimodality; second languages.

Children from Latina/o backgrounds appropriate empowering cultural resources from their families and communities, funds of knowledge (Moll, Amanti, Neff, \& Gonzalez, 1992) which researchers note may be utilized for learning in academic contexts and help uncover buried histories (Campano, 2007). The issues children live daily as emergent bilinguals who navigate linguistic, cultural, and 
national borders, however, are often framed as deficits within school contexts, particularly within the current reform agenda of high-stakes testing (Genishi \& Dyson, 2009; Zacher Pandya, 2011). Standardized school policies and practices delineate what counts as knowledge in school and what types of languages, literacies, and identities are privileged. When children's experiences are outside of what is valued in school, they may choose to silence their own stories, insights, and questions. Schools may thus reinforce ideologies of compliance and conformity that maintain privilege and reproduce patterns of power (Britzman, 2003), rather than become a means of social transformation (Freire, 1970a).

This article presents findings from a practitioner research study (Cochran-Smith \& Lytle, 2009) that sought to foreground children's communitybased knowledge and their cultural and linguistic resources within the literacy curriculum. As we explore, out-of-school experiences, when brought into the academic setting through photography, became a vehicle for critical inquiry that engaged historically rooted double binds in children's lives - moments when students are placed in the contradictory position of having to silence their stories in order to successfully navigate the official school curriculum. We focus our analysis on students' small group dialogic discussions and their multimodal writings, with specific attention to what we label as "turning points" (Abbott, 1997) - shifts in the interactions that provided opportunities for students to develop critical stances and unsettle classroom cultures of silence (Freire, 1970a).

\section{Theoretical Frameworks}

In examining emergent bilinguals' engagement within our curricular third space (Gutiérrez, 2008), we are informed by cultural-historical activity theory (CHAT) and its conceptualization of the double bind. CHAT understands learning as mediated by the cultural tools and artifacts young children appropriate in their everyday practices and activities (Cole, 1996; Engeström, 1999; Gutiérrez \& Rogoff, 2003). Importantly, CHAT shifts the focus from the individual to collective systems of activity. In our work, this entails reframing learning from 
what one student does (or does not) accomplish, to how teaching and learning are collectively negotiated in ways that might shift the trajectory of what counts as knowledge in the school literacy curriculum. Within a CHAT framework, the tensions and contradictions that arise from cultural historical activity systems are not merely obstacles, but potentially productive sites for change (Engeström, 1986). Double binds occur when a demand is imposed upon the individual but this demand itself is impossible to fulfil because a broader context forbids it. They are defined as processes in which participants repeatedly face pressing and equally unacceptable alternatives in an activity system, with no apparent way out (Bateson, 1972). We utilize the concept of the double bind as an analytic tool to better understand how dialogue which builds on the range of children's semiotic resources can potentially support critical inquiry and result in destabilizing classroom cultures of silence. By semiotic resources we refer to "actions, materials and artifacts we use for communicative purposes" (van Leeuwen, 2004, p. 285), which incorporate not only written text, but also other modes and languaging practices. The semiotic resources we spotlight in this article are children's photographs, writing, and oral storytelling. We use the notion of dialogue not solely as a tactic to involve students in a particular task, but as a collaborative way to negotiate meaning. As Freire explains, dialogue "characterizes an epistemological relationship" (Freire \& Macedo, 1995, p. 379) where creation and knowledge production are inter-subjective processes. Through dialogic inquiry, educators can integrate children's daily experiences into school settings, which may begin to make visible the social, political, and economic interests of students and their families (Freire, 1970a).

\section{Critical Stances through Dialogue}

Researchers have utilized varying analytic tools to understand inquiry with immigrant and bilingual populations. One promising area of scholarship has been the role of texts such as children's literature as a mediating tool for dialogue (Ada, 1990/2003; Leland, Lewison, \& Harste, 2013; McCaleb, 1994; Zubizarreta, 
1996). For example, Keis (2006) found that children's literature provided a platform for critical and transformative reflection within a Latino family literacy program, whereby participants could voice the inequities they were facing and imagine alternatives. Martínez-Roldán and Malavé (2004) examined picturebook conversations through discourse analysis to understand a seven-year-old Mexican student's emergent ideas about language. In their findings, the authors explore children's participation within different - and at times contrasting perspectives about language and identity, and point to how discussions around literature could engage these contradictions. Arce (2004), in a participatory research project with five Spanish bilingual teachers, found that as they brought their personal histories and experiences as Latinos growing up in a "racist, hegemonic society [...they] began a process of reconceptualization of self and their Latino community" (p. 241), suggesting that schools could be places where learning leads to social critique.

We extend the tradition of dialogue around texts by considering other semiotic modes beyond the linguistic, in particular, the visual mode. Literacy and the arts have been linked as complementary for meaning making, for providing multiple perspectives, and for fostering avenues for critical expression and understanding (e.g. Ernst, 1994; Gallas, 1994; Harste, 2014; Kiefer, 1995; Short, Kauffman \& Kahn, 2000). Dewey (1934) and Greene (2001) forged a vision of art as a liberatory pathway to make sense of lived experiences, including social inequality. Art can create opportunities for diverse children to make their voices heard (Green, 2001), not as a "separate realm" (Dewey, 1934, p. 3) or ancillary to the main curriculum, but, as we hope to show, as a mediating tool which teachers can leverage for classrooms that are more inclusive of children's experiences and community knowledge.

The potential of using images as a means to communicate can be understood through the concept of transmediation, or the process of (re)presenting meaning from one sign system to another (Siegel, 1995). Different sign systems have different potentials for meaning making (Eisner, 1994), and children employ them flexibly as tools for thinking (Short, Kauffman \& Kahn, 2000). For example, Carger (2004) found that the arts and 
multimodality supported learners utilizing the full range of their linguistic resources, and Moll, Amanti, Neff, and Gonzalez (1992) have documented how artistic experiences may tap into students' funds of knowledge. However, despite images becoming more prominent in twenty-first-century communication (Kress, 1997), within the context of school they are still often undervalued (Siegel, 2006).

In this study, we intentionally expand the idea of a text to include children's photographs that captured family and community images. Our analysis suggests that dialogue around these visuals became opportunities for inquiry and gave students permission to disclose readings that countered dominant norms.

\section{Methodology}

This article draws from a larger primarily qualitative (Erickson, 1986) and practitioner research (Cochran-Smith \& Lytle, 2009) study that examines how Spanish-English bilingual students engaged with multimodal literacy experiences we (Patricia and María Paula) designed and facilitated, including by using photography to document their families and communities. These visual texts were then used as the basis for storytelling and small group discussions, and students were invited to take a critical stance as facilitated by the researchers and through input from peers. To explore how the children interacted with community issues brought up in the photographs, we grounded our work in the following research questions: (1) What are the affordances and challenges of children bringing their family and community experiences to the foreground of the literacy classroom? (2) How can children's out-of-school experiences serve as a platform for inquiry? (3) How can multimodality mediate opportunities for children's critical inquiry? 


\section{Participants}

The context for the study is a public elementary school in a large Northeastern city in the United States. While the research is ongoing, in this article we focus on the first two years of data collection. During this period, a total of 103 first graders in a dual language program participated in 6-month cycles of instructional invitations ( 27 in each class for the first year, and 24 and 25 students in each class for the second year). 101 out of 103 participating children identified as Latina/o, and all qualified for free and reduced lunch. The majority of the children's families, and many of the children themselves, were immigrants from Latin America. Both the Spanish and the English teachers demonstrated resource orientations to the children's native languages and an appreciation for and understanding of Latina/o culture.

\section{Curricular Invitations}

We engaged children in a literacy curriculum that blended writing and technology for multimodal composing centered on children's linguistic, cultural, and experiential resources. We refer to the curriculum as occupying a hybrid Third Space (Gutiérrez, 2008) because it sought to unsettle binaries between school-community languages and literacies: hierarchies of language among varieties of Spanish and English, programmatic separations that encouraged children to utilize only one of their languages, tendencies to frame out-of-school knowledge as "informal" and a stepping stone to "formal" academic learning, and the privileging of linguistic modes of literacy. Through these curricular engagements, we took a critical sociocultural perspective on literacy (Lewis, Enciso, \& Moje, 2007; Street, 1995), and strived to collectively "generate new forms of activity" that engage the double binds encountered by students from historically minoritized social locations (Gutiérrez, 2008, p. 160). Our intention was also to expand what counts as literacy and what subjects are worth telling in a school setting. Multimodality served as a mediating tool for centering out-ofschool experiences in the literacy curriculum. Throughout, we emphasized to 
children that they could utilize any or all of their languages and draw on multiple ways of conveying meaning beyond language, in particular through visuals such as drawing or photography.

Students used low-cost digital cameras to document everyday family happenings and other community experiences, including the neighborhood spaces they frequented. These images then became the basis for critical dialogue and a range of composing practices (for a more elaborated discussion of the instructional invitations, see Martínez-Álvarez \& Ghiso, 2014). Children met in small groups with one of the researchers, sharing oral narratives while looking at photographs they chose from a computer or I-pad. The teacher/researcher responded to children's storytelling by creating space for dialogue, such as through purposeful questioning and sharing her own personal narratives.

\section{Data Collection and Analysis}

Data sources for the project included: 1) Pre and post writing samples asking students to draw and write a story about their family; 2) Children's multimodal compositions (i.e. digital texts, comics, collages); 3) Audio-recorded and transcribed class sessions, group interactions, and children's discussions of their photographs; 4) Fieldnotes and researcher reflective memos; and 5) Interviews with the teachers and students. We analyzed the qualitative data thematically in a recursive and iterative process (Strauss \& Corbin, 1998), identifying patterns both in the content of children's works and in their multimodal composing practices. This article focuses on findings from the analysis of two types of data sources as situated within the overall curriculum: audio-recorded children's small group dialogic discussions based on their photos, and the multimodal texts children created. 


\section{Findings}

Children's out-of-school experiences, when brought into the academic setting through dialogic literacy invitations, became cultural resources for critical inquiry about the world, and also helped researchers and teachers learn about the students and their communities. In this section, we present illustrative sequences of data from researcher-led small group discussions. Our analysis suggests that the Latina/o children in our study experience double binds that were initially addressed by preserving a culture of silence where smooth school social relations were maintained. However, there were instances in the discussions when the children and teacher/researcher shared alternative perspectives that created fissures within these dominant narratives and made it possible for a greater range of experiences to be voiced. We characterize these moments as turning points because they shifted the nature of the discussions and also influenced children's subsequent explorations of the topics in their multimodal writings. The photos were mediating tools in the collaborative inquiry that helped surface double binds children from minoritized backgrounds are navigating within the context of schooling.

\section{Stories about Community Figures}

Photos and stories about community figures such as police, firemen, crossing guards, and school personnel were salient in children's work. The discussion we present in this first section revolved around photographs taken by Carlos (all names are pseudonyms), one of the children in the group, posing with a policeman in the neighborhood police station, on the policeman's motorcycle, and inside his car. A sample photograph is shown in Figure 1. 


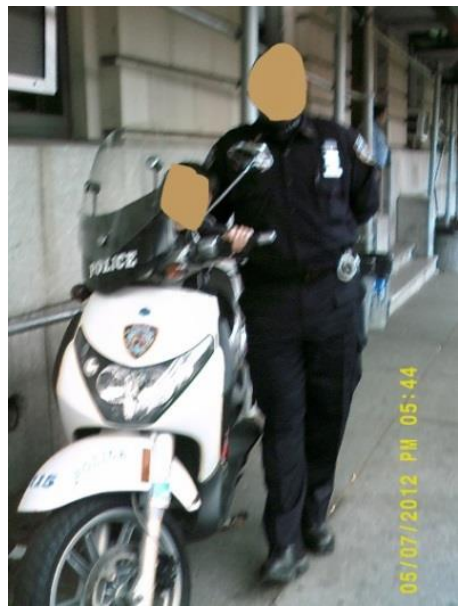

Fig.1. One of Carlos' photographs used for small group discussions

Carlos' photographs awakened much interest among the students. This was partly because the class had just finished working on a project about what they wanted to be when they grew up. Many children had chosen policemen, among other community figures, which they depicted with a variety of materials creating drawings and three-dimensional representations, such as the doll shown in Fig. 2.

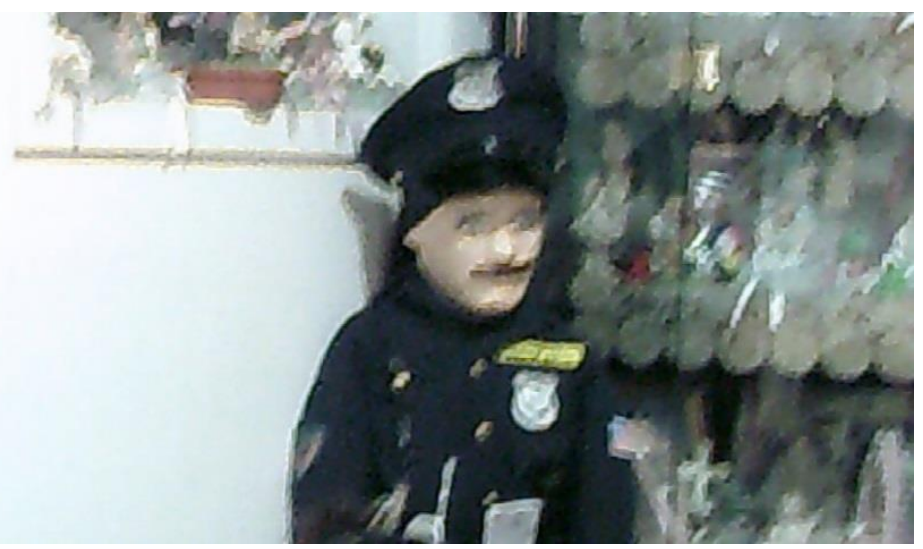

Fig. 2. Class project figure of a policeman 
The students' interest in the police-themed photographs led us to follow their lead and utilize this topic for our small group inquiries. In one group, Carlos began the discussion by describing the components of each image. While there was rich language involved and the children were all engaged, in our analysis we considered this to be an initial entryway into the topic. Over time and when provided conversational space that legitimized their experiences, children moved from more descriptive responses to the photos (i.e. "naming" its parts) to voicing more personalized connections and critical perspectives.

In order to move beyond the concrete elements of the photo, the researcher asked Carlos to explain the "story behind the picture", a discursive move to which the children had become accustomed. In response, Carlos offers an experience that, while not directly represented in the photographs, is related to his life and how he perceives the police, noting that they "protege a la gente de los ladrones" (protect people from thieves). The ideas shared through the photographs and discussion convey images of the police as warm and close to individuals like the Latina/o children in the group, as reflected by the bodily postures in Figure 1 . The police as a role the children looked up to and aspired to take on in the future is also communicated in the photograph of the class project (Fig. 2).

As the discussion continues, children portray the police as community heroes, a type of response illustrated by Kena's comments:

$\begin{array}{ll}81 & \text { Kena: } \\ 82 & \text { Es que cuando habían robado un } \\ 83 & \text { coche cerca de mi casa, y como } \\ 84 & \text { ya le dió a un viejito, porque el } \\ & \text { ladrón quería robar su coche... } \\ & \text { It's that when they had stolen a } \\ & \text { car near my house, and already } \\ & \text { it hit a little old man because the } \\ & \text { thief wanted to steal his car... }\end{array}$


In this description, Kena explains how a man almost had his car stolen. However, this person, who is situated as vulnerable in line 83 with the Spanish word for "little old man", was protected by the police who, in Kena's words "toda la noche estaban viniendo...para ver si todavía alguien está en peligro o está muerto" (the whole night [the police] was coming...to see if someone was in danger or is dead). This narrative ends with Kena emphasizing feeling scared. The level of detail Kena later adds to her narrative (such as how she couldn't get in her house when she came from school because of the police) suggests that she is recounting an event she has probably directly witnessed.

Reflecting on the experiences the children had shared, the researcher asked the group how they thought the police had acted in these different stories. To this question, the children answered with emphatic affirmative signals and then Carlos stated the following:

149 Carlos: Y sí, son unos héroes que salvan

150 esta ciudad.

Yes, they are heroes that save

this city.

153 Carlos:

Se parecen como valientes

154 que no les da ni vergüenza ni nada. They are like brave people that are not embarrassed or anything.

These few lines present an image of police as "heroes who save this city" (lines 149-150), "brave" (line 153); and as never being "embarrassed" (line 154). The exchanges appear to coalesce into a narrative of police as community heroes, which the children felt a desire to underscore. A silence remained regarding experiences with police authority that felt threatening, particularly towards communities of color. 
To explain the next turn in the direction of the discussion, our role as researchers is significant. We (Patricia and María Paula) share with the children identities as Latinas, native Spanish speakers, and immigrants to the United States. These overlapping experiences help us be attuned to the possibility of other, less positive, experiences with police, which had not been represented up to this point in the discussion. Thus, to create a space within our inquires for such perspectives, the researcher facilitating the group dialogue (Patricia) decided to share an incident she had experienced which portrayed a different point of view. The story begins with Patricia explaining that when her daughter was only a few months old, she started to cry loudly at midnight, and she wouldn't stop crying. Patricia went on to explain that she heard someone knocking on the door, and it was the police. In the following exchange, the children and researcher discuss the impact of the police arrival:

$\begin{array}{lll}268 \text { Researcher: } & \text { ¿Cómo me sentí? ¿Qué pensé yo? } \\ & \text { How did I feel? What did I think? } \\ 269 \text { Carlos: } & \text { Usted pensaba como que la iban } \\ 270 & & \text { a molestar porque también... } \\ & \text { You thought that they were going } \\ & \text { to bother you because also... } \\ & & \\ 275 & \text { Ana: } & \\ & & \text { Y que la pueden llevar, } \\ & & \text { o quizás a su papá o a su mamá. } \\ & & \text { And that they could take her, } \\ & & \text { or maybe her father or her mother. } \\ & & \end{array}$

The children's exchanges present ideas that complicated previous onedimensional images of police authority, and which in analyzing the data seemed to have an impact on the direction of both this conversation and the children's 
subsequent explorations of this subject. This pattern led us to characterize this portion of the dialogue as a "turning point." In Cultural Historical Activity Theory, turning points signal changes in the "overall direction" (Abbott, 1997, p. 93) of the interactional context. They require a backward-looking perspective for tying together three points: A prior steady state, a critical event, and the ensuing establishment of a new trajectory (Abbott, 2001, as cited in Yair, 2009). In the above example, the steady state corresponds to the initial exchanges during which children share only those experiences that match a view of policing as unequivocally positive. We conceptualized the critical event as the part of the dialogue where the researcher engages children in discussing the impact of the police coming to her house at night to check on the crying baby. The data following the researcher's story shows how this experience opens up a space where voicing alternative experiences with police is possible and allowed.

Carlos, in the above lines 269 and 270, offers a feeling of vulnerability many feel towards the authority of the police in stating that maybe the baby's mother (the researcher) thought that they were going to "bother" her. Furthermore, in lines 275 and 276 Ana presents the idea that the police could take the baby or one of the parents. Here, Ana speaks up regarding a prevalent threat for Latino families, of which we found many of the children keenly aware. It is a reality that in the United States many Latina/o immigrant children live with the fear that their parents might be taken away if the police confront them, particularly if they are undocumented. These feelings of insecurity in relation to the police force were further revealed as the dialogue continued:

\begin{tabular}{|c|c|c|}
\hline \multirow[t]{2}{*}{327} & Carlos: & \\
\hline & & Maybe she could be scared. \\
\hline \multirow[t]{2}{*}{328} & Researcher: & ¿Quién? \\
\hline & & Who? \\
\hline \multirow[t]{2}{*}{329} & Carlos: & El bebé. \\
\hline & & The baby. \\
\hline 330 & Researcher: & El bebé está asustado? \\
\hline
\end{tabular}


The baby is scared?

331 Carlos:

Porque a veces algunas mamás

332 se asustan y empiezan a llorar

333 con el bebé.

Because sometimes some mothers get scared and start crying with the baby.

The children shift attention away from the baby's mother (the researcher) and onto the baby, who, as shown in lines 327-332, could also be scared by the police. This section of the discussion suggests children's awareness of a shared vulnerability in the face of police authority that impacts the family as a whole.

As the discussion continues, Ben, one of the children, notes:

337 Ben:

338

339

\author{
En España, ¿tienes perros? Si \\ ladran mucho mucho mucho, \\ también llaman a la policía aquí. \\ In Spain, do you have dogs? If \\ they bark a lot a lot a lot, \\ they also call the police here.
}

In these lines, Ben presents a parallel story where the police is summoned because one is disturbing others, thus building on the critical event and attempting to add to the new trajectory in the discussion. He asks about dogs in the researcher's country of origin (line 337), and compares the situation to the Unites States, making links across countries and cultural norms. His final sentence in line 339 stating that they "also" call the police "here" shows Ben's understanding that such acts are present in the United States, but maybe not in other parts of the world. Afterwards, Ana returns to the idea that when the baby was crying it was because she was scared, and Carlos affirms that the baby "es muy chiquita para que la arresten" (is too young to be arrested). These comments reveal the presence of a range of feelings and experiences regarding 
the police that were not captured within the initial characterization as "heroes who save this city."

Analysis of the data shows that once the new trajectory had been established, it continued beyond the particular group dialogue, which contributes to our characterization of the exchange around the researcher's narrative as a turning point in the activity of the children's inquiries within our curricular invitations. Following the discussion, children expressed a greater range of views of the police based on personal experiences. For example, Keith, one of the children who had participated in the small group, decided to write about this issue. Since his own photographs had not captured the police as a topic, he asked Carlos if we could borrow a copy of his photos and then pasted his own likeness atop Carlos', thus redesigning the image as if he were posing with the policeman. His translated text reads:

\begin{abstract}
"The policeman was with the child the child was holding the door and also the policeman. Once I was going to go to school and I saw many policemen and I waited for the bus and it wasn't coming and then the bus came and I went inside and then when the bus went around the police left. The policemen were there because they had thrown much garbage and I heard the noise of the car and I saw that they had left tickets on the door and my grandmother didn't see it and all my family didn't see it either."
\end{abstract}

His written story was complemented with an oral description that we documented in our field notes as follows:

"While working with Keith in his writing from Carlos' photograph he explained that the police had given his family a ticket (which was posted to their apartment door for littering). According to Keith, his family had not been the ones who had thrown all the garbage in front of their 
house. Keith explained how his family felt very worried because they didn't have the money to pay for the ticket."

In this instance, the photograph Keith borrowed served as a mediating artifact for surfacing counter-narratives regarding Latina/o young children's lived experiences with law enforcement. Keith recognized that the photograph Carlos had brought into the classroom could serve as a semiotic resource for communicating his story, and he agentively adopted it for his own purposes. The children's photos and their related experiences were not only individual accounts, but contributed to a more nuanced collective representation of issues they identified as important.

Stories sharing multifaceted views of police presence may have been initially left out of the academic space in an effort to preserve a culture of silence (Freire, 1970a). This silence is related to a historical double bind where the children might have experiences with social inequality (such as police profiling) but calling attention to these realities given the racialization of Latina/o communities may make them more vulnerable to city authorities and institutions. Thus, students may find it easier to silence alternative narratives and align themselves, at least on the surface, with dominant ideologies (Ghiso \& Campano, 2013). Teachers and researchers, as representatives of institutions of power, may reinforce certain dominant tropes about community figures that, by not fully accounting for the range of realities experienced by the children, may assist in the historical process of assimilation for immigrant communities.

\section{Stories of Children's Worlds and Cultural Values}

The dialogic exchanges we present in this section were sparked by a series of photographs children brought back after the winter holidays. Themes such as religious traditions, family, and celebration were evident in the visuals the children had captured, and a significant portion portrayed toys and presents. Several children decided to utilize photographs of toys for writing, and they 
created multimodal compositions that generated much interest among other classmates. Two such pieces are shown in Figure 3.
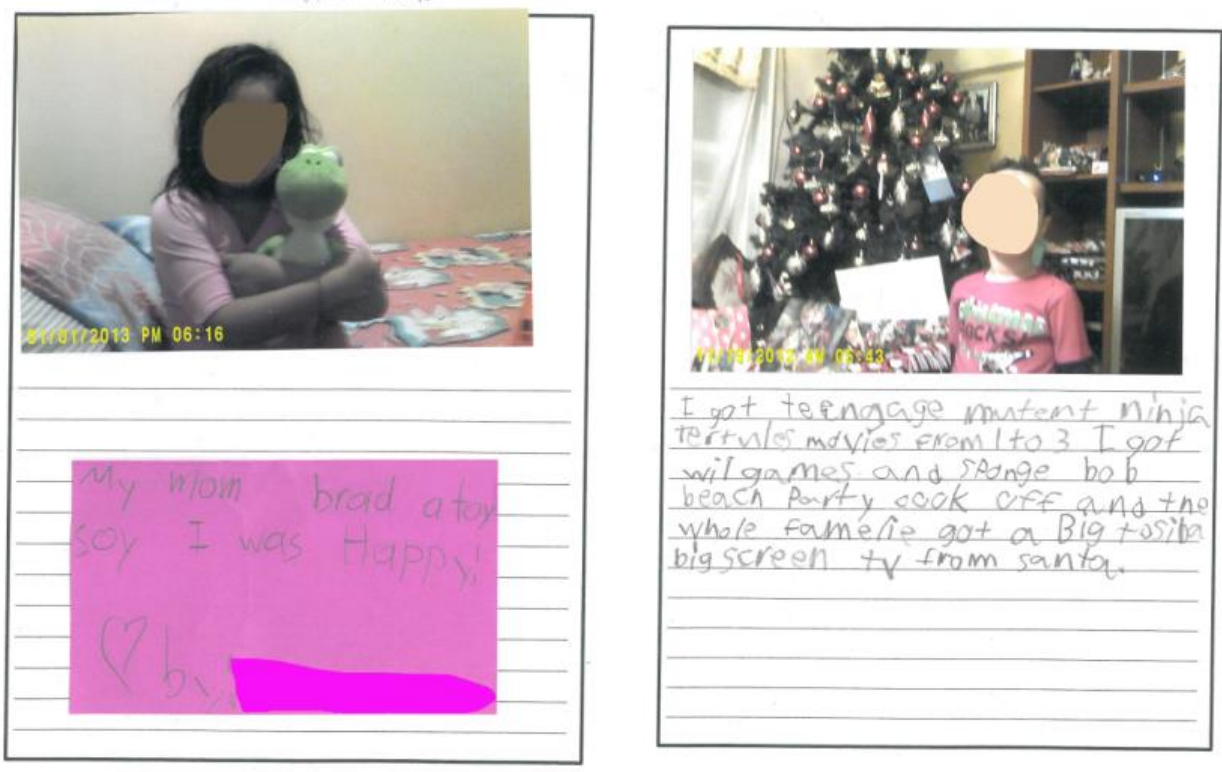

Fig. 3. Nina's and Bernardo's work in relation to toys

To the left of figure 3, we show Nina's photograph as she hugs one stuffed animal that appears to be a dinosaur. The accompanying bilingual text on this initial writing reads, "My mom brad [brought] a toy soy I was Happy!" In moves that connoted Nina's agency in employing her multiple linguistic resources, she wrote, "I was" in English but preceded it by its Spanish translation "soy". She also emphasized the work "Happy" by capitalizing it and adding an exclamation mark, and drew the symbol of a heart before signing her name. The words were written on a post-it because during this initial chance for children to share their photos with peers, they discussed them orally and then jotted some ideas for further writing. To the right of Fig. 3, Bernardo's composition shows him clad in a red t-shirt with the words "Christmas Rocks" emblazoned on it, as he stands 
next to a heavily decorated tree at the bottom of which we see numerous gifts wrapped in colorful paper. Beneath his picture, Bernardo enumerates the numerous presents he received from Santa. His list includes several elements from pop culture, such as the Mutant Ninja Turtles movies numbers 1 through 3, as well as a family gift, a "Big Toshiba big screen TV." Bernardo directs the readers' attention to the word big, which he includes twice and capitalizes. The children's writings communicate the substantial material rewards of the holiday season and the links between such gifts and happiness.

After witnessing the children's interest in toys, we decided to explore these ideas in the small group discussions. The excerpts below are from one of the groups, consisting of six children: Esteban, Sandra, Ben, Nina, Fani, and Kira. The conversation started with Sandra stating that her mom had bought her many toys and that she was very happy. As the exchange continues, this notion of happiness is emphasized, and Sandra draws on her transnational experiences to present a scenario of upward mobility:

$\begin{array}{lll}08 \text { Sandra: } & \text { Y me siento muy feliz porque } \\ 09 & \text { mi mama también me compra } \\ 10 & \text { como tengo } 100 \text { y yo juego con } \\ 11 & \text { eso y por eso soy muy feliz. } \\ & \text { I feel very happy } \\ & \text { because my mom also buys me } \\ & \text { like I have } 100 \text { and I play with that } \\ & \text { and because of that I am very happy. } \\ & \text { Y, ctú crees que a todos los niños } \\ & \text { les compran tantos juguetes como a ti? } \\ 12 & \text { And do you think that all the children } \\ 13 & \text { get as many presents as you? } \\ & & \text { Unos niños no porque son pobres } \\ 14 & \text { y no tiene padres. }\end{array}$

Some children no because they are poor and they do not have parents 


$\begin{array}{lll}21 & \text { Sandra: } & \text { Ella siempre me compra. } \\ & \text { She always buys me. } \\ & \text { Me siento feliz por ella } \\ 24 & \text { Sandra: } & \text { es mi mejor mamá que hay. } \\ & \text { I feel happy for her } \\ & \text { she is my best mom that there is. }\end{array}$

During this exchange Sandra seems to discern poverty as the reason for some children not to have toys (see line 14), characterizing it in a distant manner as she explains in line 15 that this is what happens to children who don't have parents. The salience of Nina's own parents in her account portray her as outside this category. In line 21 Sandra suggests that her mom is able to buy her all the toys she wants, as she once again makes the connection between happiness and being able to buy many toys (line 24), explaining that her mom is the best mom there is and implying that being the best mom is related to the fact that she buys her all the toys she wants. The discussion continues in this vein as others explain how they were very happy because their parents bought them all the presents they wanted, and interject with accounts of the unimaginable amounts of toys that they received, such as Esteban who stated "Mmm, solo 400 juguetes" (Mmm, only 400 toys). The children align themselves and their happiness with the material possessions they receive from their parents, and distance themselves from economic hardships as happening to "some children" far from their own realities.

However, there is a moment in the conversation where Ben offers a different perspective, stating in Spanish that his parents only buy him one toy... his favorite one. Moreover, Ben rationalizes that if parents buy too many toys "iSe te explota la casa! iSe te explota la casa!" (Your house is going to explode! Your house is going to). He performatively represents the explosion, loudly vocalizing its sound and exaggeratedly moving his arms to denote its impact. This critical event becomes a turning point that creates openings for sharing perspectives that counter the images of economic security and happiness 
through materialism previously invoked by the children. Nina and Fani build on Ben's perspective and continue to expand the dialogue in a different trajectory as they explain:

106 Nina:

107

108

112 Researcher:

113

114

115 Fani:

116 Researcher:

117 Fani:

118 Researcher:

119

120 Fani:

121

122
Aunque no me compren

los juguetes todos, no importa.

Yo todavía estoy feliz.

Even if they don't buy me

all the toys, it doesn't matter.

I am still happy.

Fani, ¿qué te parece?

$¿ A$ ti te compran todos los juguetes

que quieres, tus papás?

Fani, what do you think?

Do they buy you all the toys

that you want, your parents?

No mucho...

Not much...

¿No mucho? ¿Por qué no?

Not much? Why not?

Porque a veces no tienen plata.

Because sometimes they don't have money.

iAhh! Porque no tienen plata.

Y, entonces, ¿Como te sientes tú?

Ahh! Because they don't have money.

And, then, how do you feel?

Entonces, un poquito triste

pero y mi papi me dice

que me va comprar uno mañana.

Then, a little sad

but and my daddy tells me 


$\begin{array}{lll} & & \text { that he will buy me one tomorrow. } \\ 123 & \text { No no me siento triste } \\ 124 & & \text { si no me compran. } \\ & \text { I don't feel sad } \\ & \text { if they don't buy me. } \\ & \text { ¿Por qué no? } \\ & \text { Why not? } \\ 125 \quad \text { Researcher: } & \text { Porque cuando... es solo } \\ 127 & & \text { una cosa. Y un juguete es } \\ & & \text { una cosita... } \\ & \text { Because when... it's only } \\ & \text { one thing. A toy is only a } \\ & \text { little thing... }\end{array}$

Ben, Nina, and Fani express alternative ideas to the perspectives shared earlier in the conversation, and decouple happiness from the amount of goods one possesses. Issues of monetary hardship (rather than economic flourishing) appear in line 117 and continue beyond the above excerpt, as Fani explains how financial issues influence social relationships and the constraints of work commitments: "es como que a veces mi mami no se va como la mamá de Nina ni Esteban porque como que no tiene mucha plata y a veces los domingos o los domingos a veces trabaja" (some times my mommy does not go with like Nina's mother or Esteban's because like that she does not have a lot of money and sometimes on Sundays, sometimes she works).

In subsequent statements, Fani shares varied and contrasting perspectives on the issue:

\begin{tabular}{|c|c|c|}
\hline 153 & Fani: & Mi papá también a veces \\
\hline 154 & & tiene menos dinero, pero ellos \\
\hline 155 & & usan su dinero para comprarme \\
\hline 156 & & cosas que yo quiero, porque \\
\hline
\end{tabular}


157

158

159

160

161

162 ellos me quieren. $Y$ me siento tan feliz porque yo, pero a veces no tengo dinero para comprar juguetes. $Y$ no importa, tú todavía tiene estar feliz... Con Dios

My dad also sometimes

has less money, but they use their money to buy me things that I want, because they love me. And I feel very happy because $I$, but sometimes I don't have money to buy toys...And it doesn't matter, you still have to be happy... With God.

In lines 156-158 of this section of Fani's oral narrative, she confirms the previously expressed idea of buying things as signaling love and making one happy. However, in lines 160 through 162, she also explains how one can find fulfillment in other aspects of life apart from material acquisitions. Fani's comments illustrate how children's ideas around the historical double binds that impact them are not linear but dynamic, and may manifest in contradictory perspectives.

Contributions by Ben, Nina, and Frida became turning points that took their inquiries into material possessions and relative wealth in new directions. Nina, for example returned to her writing, and replaced her post-it with a more elaborated text that went beyond her initial assertions (Fig. 4). 


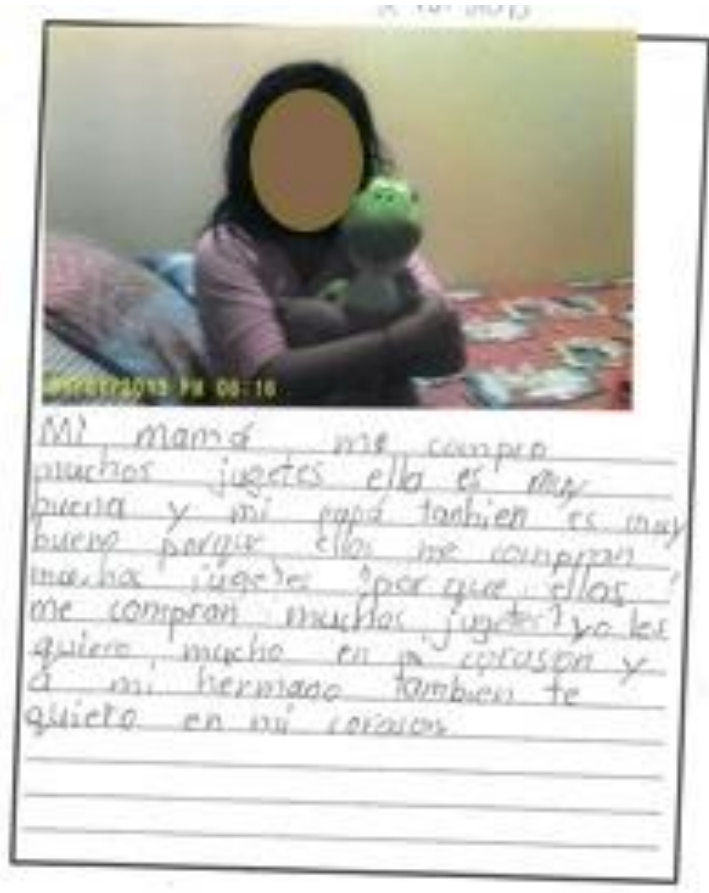

Translated text:

My mom bought me many toys she is nice and my dad is also very nice because they buy me many toys. Why do they buy me many toys? I love them a lot in my heart and my brother I also love you in my heart.

Fig. 4. Nina's expanded text

Nina's piece begins with a link between her parents' character (their "niceness" or "goodness") and their toy purchases. This representation, however, is followed by an addition directly questioning their purposes for buying these toys. The text ends with Nina proclaiming her love for her parents and also for her brother, who is not in a position to buy her gifts. The small group dialogues in which Nina took part appear to have informed her exploration of the topic and what she chooses to convey in her writing.

An exchange around José's composition, shown in Fig. 5., situated the children's discussion of toys within a transnational framework that drew on their histories of immigration and bicultural identities as an epistemic resource. 


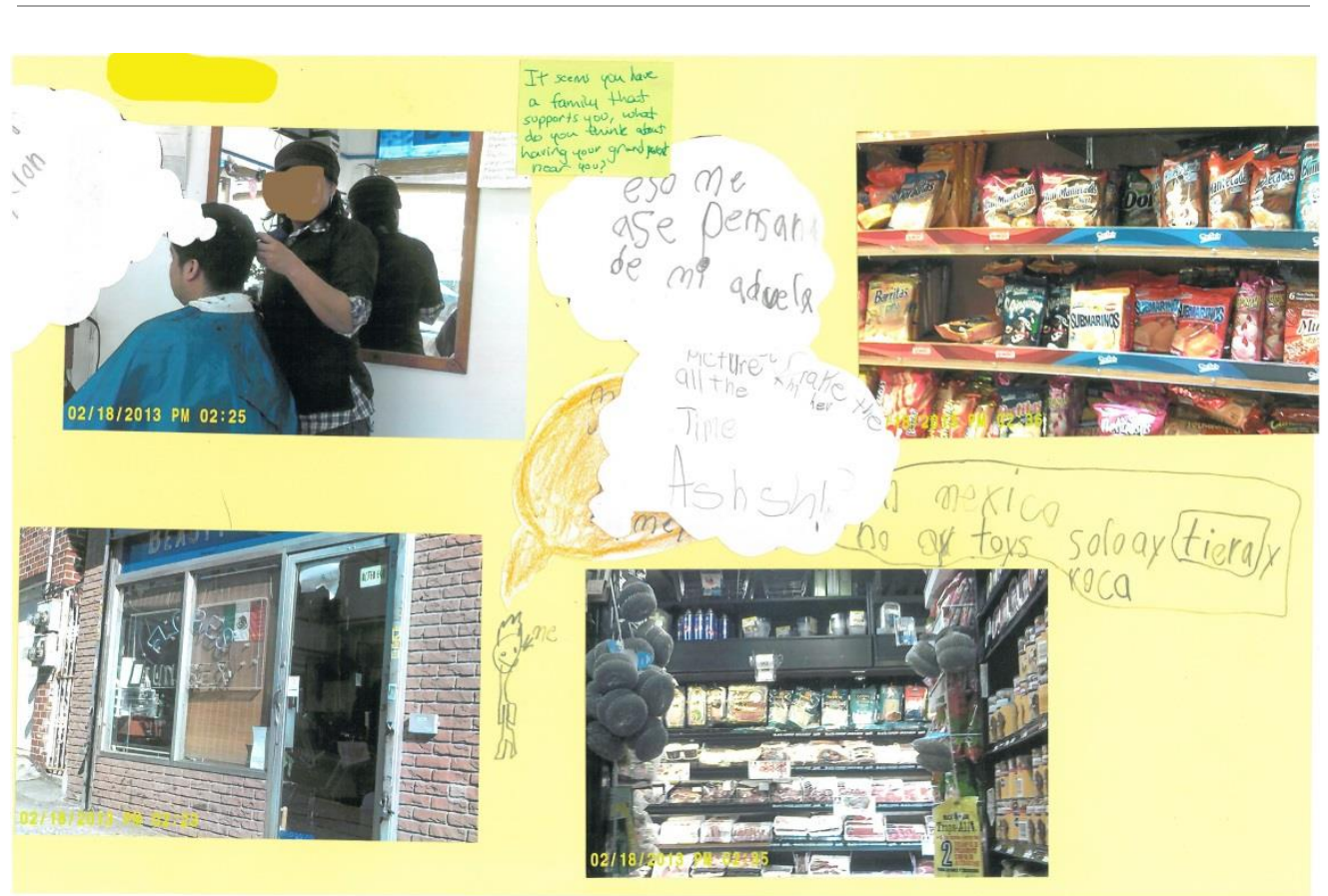

Fig. 5. José's multimodal composition

In the thought bubble located in the center of his multimodal text, José indicated that the photographs he is using made him think of his grandmother (referring to the image in the bottom left showing a storefront decorated with the Mexican flag). To the right, he added, "en Mexico no ay [hay] toys solo ay [hay] tiera [tierra] y roca" (In Mexico there are no toys, there is only soil and rock). This statement awakened commentary on the issue from José's classmates, many of who also are also of Mexican descent. Sandra, Nina, Leo, a fourth unidentified student, and the researcher (Patricia) were working together as the following dialogue took place:

86 Sandra:

87

88

89
Ummm... que todos los países

no son... Todos los países no son

lo mismo pero en México, hay

tierra y roca, pero no hay toys, 
90

91

109 Leo:

110

111

114 Other:

115 Researcher:

116 Student:

118 entonces, sí, acá hay toys y hay

cosas, y hay dinero.

Ummm...that all countries

are not... All countries are not

the same, but in Mexico, there is

soil and rocks, but there aren't toys,

so, yes, there are toys here, and

there are things and there's money.

En México no tienen dinero,

tienen poquito y no tienen para

comprar cosas.

In Mexico they don't have money,

they have very little and they

don't have enough to buy things.

En México no tienen.

They don't have in Mexico.

Ujum.

Uhum.

En México, no tienen mucho

dinero para comprar juguetes.

$\mathrm{Y}$ otros no tienen tienda de juguetes.

In Mexico, they don't have much

Money to buy toys.

And others don't have toy stores.

In this conversation, the children present emerging understandings of inequality, and their transnational backgrounds become a resource in situating economic considerations within a world-systems framework (Saldivar, 2011) where, in the words of Sandra, "all countries are not the same." How that difference is explored, and the role of educators in facilitating such inquiries, has the potential to voice silences and social critique, or could reinforce ideologies of 
"First World" progress and immigration as assimilation. In this exchange and throughout the study, children drew on transnational perspectives to shift the conversation beyond a US-based one, an impulse we believe is important to engage. We worried, however, about children's comments coalescing into a singular representation of Mexico. The majority of the children had never been there and their statements were often based on stories they heard from relatives. It is certainly the case that many families in Mexico suffer financial hardships, which often becomes the impetus for immigration. We wondered as well about the kinds of positionings produced through these narratives. For families separated from extended relatives and experiencing social and political precarity in the US, an economic standing characterized as improved may frame current challenges within a national narrative of meritocracy and upward mobility (Parini, 2012). Inquiring into these ideas requires following children's leads in linking local issues to global contexts, but also supporting them in interrogating "single stories" (Adichie, 2009) of any one country and the power relations across countries that produce inequality.

Throughout our study, it was evident that economic matters were a common theme, and the children used all the semiotic tools at their disposal to bring this topic into the school curriculum. Carla, for example, staged the following series of photographs, three of which are shown in Figure 6.
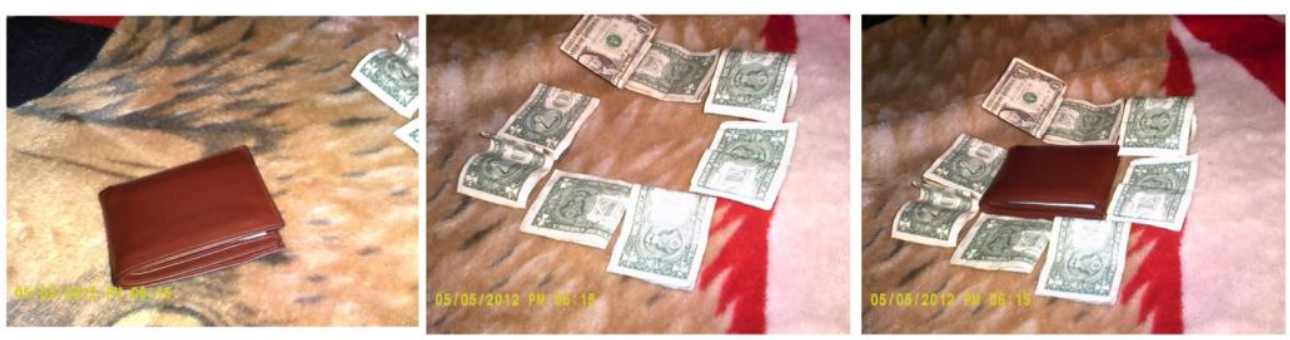

Fig. 6. Carla's photographs about the subject of money

In the first image, a brown leather wallet is shown by itself, then in the second photograph, one-dollar bills are shown surrounding a non-existent wallet, and in 
the composition on the right, both the wallet and the money are shown, with one-dollar bills tightly surrounding the former. Whatever the intended purpose of this text, it is clear that money was a topic of importance to Carla and her peers. Once the silence about economic hardships was disrupted - and the unilateral want for an ever-increasing number of toys stemmed - a fuller range of children's experiences around finances could enter the curriculum. At times, these references were abstract, like Carla's images, which leave the audience with an impression of the subject matter but without details as to its role in children's lives. Other instances were more concrete, like Brenda's multimodal writing, shown in Figure 7, which poignantly showcases what is often left unsaid in the stories children tell in school.

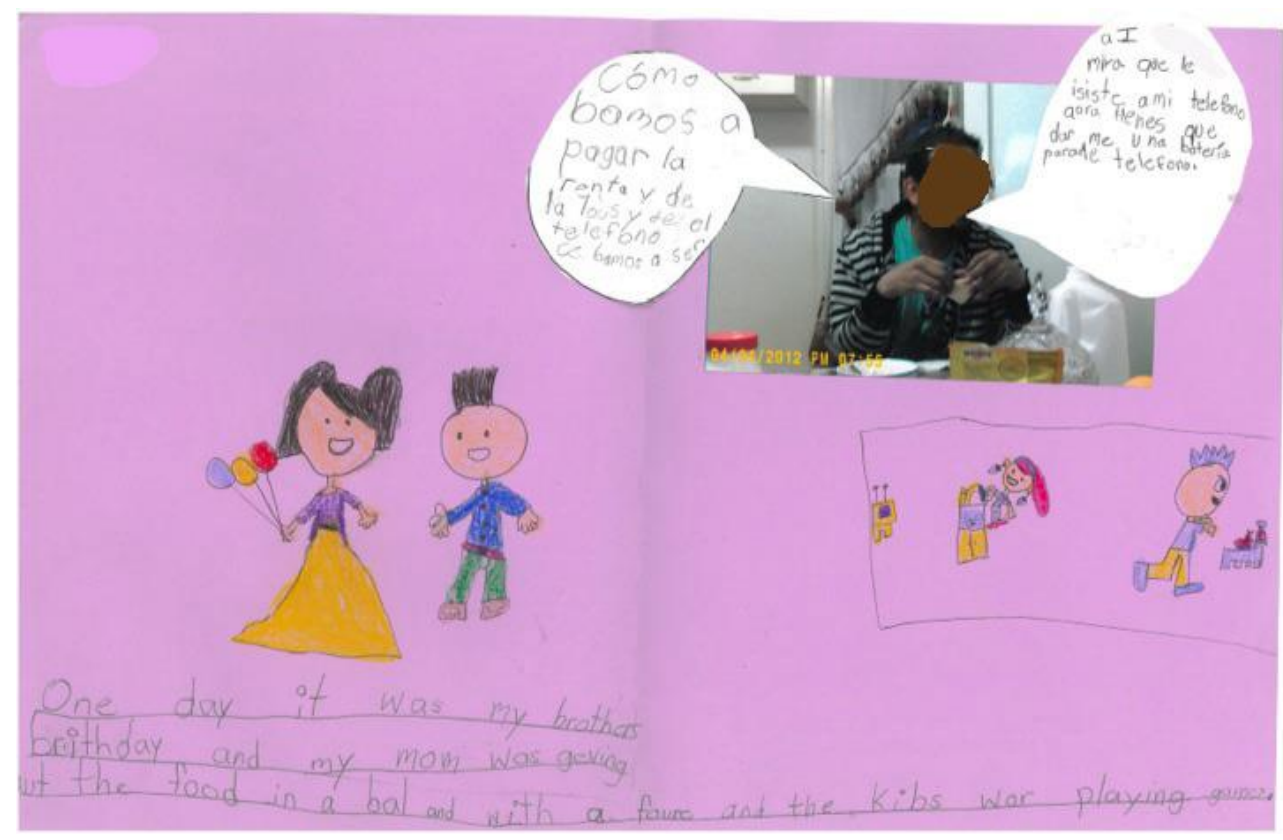

Fig. 7. Brenda' multimodal writing 
In the lower portion of Brenda's work is a common narrative about a birthday celebration, with balloons, food, and games, but in the top right hand corner, we see a less frequently represented experience. Brenda renders her dad's perspective as he worries about monetary instability, stating "cómo vamos a pagar la renta y la lous [luz] y de el telefono ce [que] bamos [vamos] a ser [hacer]" (how are we going to pay the rent and the light and the phone [bills]? What are we going to do?). Brenda switched to her home language for this section of the text, conveying her dad's concerns in a manner that characterizes the family realm where such matters are discussed. We believe that being able to draw on various languages and on multiple modes of representation may have been an affordance for the children, giving them a wider range of tools to convey the full range of their experiences.

The work highlighted in this section speaks to a broader historical double bind impacting students from immigrant backgrounds. In children's discourses we saw cultural values and practices of interdependence (Ghiso, in press), which we suggest may be magnified by the vulnerability families feel as the result of social and economic precarity. The message that caring for one's family members comes above all other principles, and emphasis on finding comfort beyond material resources such as toys, was strongly present in the children's dialogues and work. On the other hand, upon coming to the United States families are confronted with meritocratic ideologies where success and happiness are measured by individual attainments, often economic, as concretized for children in the form of toys or electronic devices. Sharing economic hardships, when material resources are often equated with fulfillment, has the potential to cast doubt on a family's standing and "worth." Our data shows how Latina/o emergent bilinguals grapple with this pressing double bind on their daily interactions in the classroom context - expressing practices of collectivity and interdependence and also identifying the individualism that shapes social institutions such as school, at times critiquing and also espousing economic markers of achievement. Children might readily offer an "appropriate" response to satisfy the teacher and/or classmates, even if they also hold other perspectives or values (Ghiso \& Low, 2013). Thus, unless opportunities are 
explicitly created for critical inquiry, and spaces made to share dissenting or contrasting viewpoints to dominant ideologies, classroom curricula may contribute to replicating assimilationist orientations.

\section{Engaging Double Binds for Critical Inquiry with Young Children}

Many of the Latina/o students and their families in this study were certainly vulnerable to state and police power, particularly those who themselves were undocumented or who had parents or loved ones without papers. In fact, during the period of this research, several children involved in the larger project had parents detained and deported. However, as the data also reveals, building off a long tradition in critical theory (e.g., Althusser, 2001; Gramsci, 1971), power also operates through cultural, civic, and educational institutions, what Althusser identified as the "ideological state apparatus". The dominant ideologies perpetuated in contexts such as schools are not necessarily explicit political belief systems, for example around immigration policy, but rather reflect more subtle assumptions regarding how the social world operates, what Althusser (2001) has defined as one's imaginary relationship to the real conditions of one's existence. Two related ideologies that the children themselves initially perpetuated in their conversations concerned how the nation state justly and consistently adjudicates individual responsibility for behavior and the meritocracy thesis, the idea that hard work will invariably be rewarded with material wealth, which then becomes the primary marker of human value. Both ideologies locate failure and success within individuals, and by implication their families and communities. They also silence deeper systemic inequities that disenfranchise communities, not just within the United States but internationally wherever there are minoritized communities.

When these silences are left unexplored in classrooms, students may invariably consent to dominant ideologies and perhaps even internalize a sense of failure or criminality, what Gramsci (1971) characterizes as a form of "cultural hegemony." Yet probing these silences is much easier said than done, especially 
when the curriculum is geared toward standardization and the efficiency. Our research has suggested that Cultural Historical Activity Theory, with its analytic focus on double binds and turning points, may be useful for a critical pedagogy (Freire, 1970) that strives to identify fissures within dominant ideologies from which the potential for alternative understandings of social phenomena arise. These alternative understandings may be more empowering for students in that they better explain the complexity of their lived experiences and provide opportunities for them to name injustice.

The dialogic exchanges around the two themes we have spotlighted in this article showcase how the lived experiences of Latina/o emergent bilinguals can become resources for critical inquiry. In the different scenarios, we have situated children's contributions as manifestations of historically rooted double binds that derived from their immigration histories and transnational identities. Analysis of these discussions in relationship to the children's multimodal writings revealed the existence, in each of the cases, of critical events that consequently transformed the direction of the collective activity and thus could be characterized as turning points in our joint teaching/learning community.

In our data we identified many other themes which presented opportunities for taking up and nurturing critical stances: safety in neighborhoods (e.g., parks where children cannot be alone); feelings/perspectives of others (e.g., parents, pets, or zoo animals); dynamics of inclusion and exclusion in social spaces (e.g., how language and race impact who plays together in the local park); education (e.g., finishing homework despite being tired, family and out-of-school literacies); children as technology experts (e.g., Angry Birds, Wii, cell phones); and family roles and values, including the hybridity of play and work (e.g., helping with cooking, doing laundry, caring for pets, caring for younger siblings). By directing the photographic gaze and selecting the images for discussion, young emergent bilinguals exercised agency and brought issues to the forefront of school-based learning that are often buried within dominant accounts. Children's discussions may be a platform for fostering critical consciousness (Freire 1970a, 1970b, 1973 , 1985), which begins with the recognition of a system of oppressive 
relations and one's own place in that system. In some cases, the children's conversations showed understandings of inequality not available to the researchers, suggesting the importance of learning from students about the knowledge they bring (Campano, Ghiso, \& Sánchez, 2013). In others, the dialogues surfaced contesting ideologies and had the potential to reify dominant assumptions, pointing toward the need for more extended investigations into these topics.

Too often the resources of emergent bilinguals are seen as a vehicle for acculturation into the existing curriculum. If we accept the premise that "knowledge is not neutral, and particular types of knowledge are academically validated in schools" (González \& Moll, 2002, p. 625), then educators and researchers have a responsibility for expanding what is seen as worth of knowing within school contexts, in order to work toward a more just and inclusive transformative curriculum. Multilingual children have important knowledge gained from their communities and their experiences in navigating multiple, and at times contrasting, cultural norms, and it is imperative that educators find ways to honor and learn from their insights. This might entail valuing different ways of conveying meaning, such as through visual modes or multiple languages, explicitly eliciting different perspectives on issues, providing ways for students to decide the topics from their lives they want to explore, or opening the classroom doors to families and communities. For multilingual youth in transnational contexts, the double binds they experience may be rooted in a broader historical contradiction of immigration: the pressure to assimilate (by, for instance, aligning oneself with dominant norms and ideologies around individuality and meritocracy) while at the same time being ascribed identities as "perpetual foreigners" (e.g. Devos \& Banaji, 2005), rendering full inclusion an impossibility. Probing these double binds, rather than suppressing them, may provide an initial way forward. 


\section{References}

Abbott, A. (1997). On the concept of turning point. Comparative Social Research, 16, 85-105.

Ada, A. F. (2003). A magical encounter: Spanish language children's literature in the classroom. Boston, MA: Allyn \& Bacon.

Adichie, C. (2009). The danger of a single story. Retrieved from http://www.ted.com/talks/chimamanda_adichie_the_danger_of_a_single_ story.html

Althusser, L. (2001). Learning and philosophy and other essays (B. Brewster, Trans.). New York, NY: Monthly Review Press.

Arce, J. (2004). Latino bilingual teachers: The struggle to sustain an emancipatory pedagogy in public schools. International Journal of Qualitative Studies in Education, 17, 227-246.

Bateson, G. (1972). Steps to an ecology of mind. New York, NY: Ballantine Books.

Britzman, D. P. (2003). Practice makes practice: A critical study of learning to teach (rev. edn). Albany, NY: SUNY Press.

Campano, G. (2007). Immigrant students and literacy: Reading, writing, and remembering. New York, NY: Teachers College Press.

Campano, G. Ghiso, M. P., \& Sánchez, L. (2013). "Nobody one knows the...amount of a person": Elementary students critiquing dehumanization through organic critical literacies. Research in the Teaching of English, 48(1), 97-124.

Carger, C. L. (2004). Art and literacy with bilingual children. Language Arts, 81, 283-292.

Cole, M. (1996). Cultural psychology: A once and future discipline. Cambridge, MA: Harvard University Press.

Collins, P. H. (2000). Black feminist thought: Knowledge, consciousness, and the politics of empowerment. New York, NY: Routledge.

Cochran-Smith, M. \& Lytle, S. L. (2009). Inquiry as stance: Practitioner research in the next generation. New York, NY: Teachers College Press. 
Devos, T., \& Banaji, M. R. (2005). American= white? Journal of Personality and Social Psychology, 88(3), 447-466.

Dewey, J. (1934). Art as experience. New York, NY: Minton, Balch.

Eisner, E. (1994). Cognition and curriculum reconsidered. New York, NY: Teachers College Press.

Engeström, Y. (1986). The zone of proximal development as the basic category of educational psychology. The Quarterly Newsletter of the Laboratory of the Comparative Human Cognition, 8, 23-42.

Engeström, Y. (1999a). Activity theory and individual and social transformation. In Y. Engeström, R. Miettinen, \& R.-L. Punamäki (Eds.), Perspectives on activity theory (pp. 19-38). Cambridge: Cambridge University Press.

Erickson, F. (1986). Qualitative methods in research on teaching. In $M$. C. Wittrock (Ed.), Handbook of research on teaching (3rd ed.) (pp. 119161). New York, NY: MacMillan Press.

Ernst, K. (1994). Picturing learning: Artists and writers in the classroom. Portsmouth, $\mathrm{NH}$ : Heinemann.

Freire, P. (1970). Pedagogy of the oppressed. New York, NY: Continuum.

Freire, P. (1970b). Cultural action for freedom. Cambridge, MA: Harvard Educational Review.

Freire, P. (1973). Education for critical consciousness. New York, NY: Seabury.

Freire, P. (1985). The politics of education: Culture, power, and liberation. South Hadley, MA: Bergin Garvey.

Freire, P. \& Macedo, D. P. (1995). A dialogue: Culture, language, and race. Harvard Educational Review, 65, 377-402.

Gallas, K. (1994). The languages of learning: How children talk, write, dance, draw, and sing their understanding of the world. New York, NY: Teachers College Press.

Genishi, C., \& Dyson, A.H. (2009). Children, language, and literacy: Diverse learners in diverse times. New York, NY: Teachers College Press.

Ghiso, M. P. (in press). The Laundromat as the transnational local: Young children's literacies of interdependence. Teachers College Record. 
Ghiso, M. P., \& Campano, G. (2013). Coloniality and education: Negotiating discourses of immigration in school and communities through border thinking. Equity and Excellence in Education, 46(2), 252-269.

Ghiso, M. P., \& Low, D. E. (2013). Students using multimodal literacies to surface micronarratives of United States immigration. Literacy, 47(1), 26-34.

González, N., \& Moll, L. C. (2002). Cruzando el puente: Building bridges to funds of knowledge. Educational Policy, 16, 623-641.

Gramsci, A. (1971). Selections from the Prison Notebooks of Antonio Gramsci. New York, NY: International Publishers.

Greene, M. (2001). Variations on a blue guitar: The Lincoln Center Institute lectures on aesthetic education. New York, NY: Teachers College Press.

Gutierrez, K. D. (2008). Developing a sociocritical literacy in the third space. Reading Research Quarterly, 43(2), 148-164.

Gutiérrez, K. D., \& Rogoff, B. (2003). Cultural ways of learning: Individual traits or repertoires of practice. Educational Researcher, 32(5), 19-25.

Harste, J. (2014). The art of being critically literate. Language Arts, 92(2), 90102.

Jackson, A. Y., \& Mazzei, L. A. (2012). Thinking with theory in qualitative research: Viewing data across multiple perspectives. New York, NY: Routledge.

Keis, R. (2006). From principle to practice: Using children's literature to promote dialogue and facilitate the "coming to voice" in a rural Latino community. Multicultural Perspectives, 8, 13-19.

Kiefer, B. (1995). The potential of picturebooks: From visual literacy to aesthetic understanding. Englewood Cliffs, NJ: Merrill.

Kress, G. (1997). Before writing: Rethinking the paths to literacy. London, UK: Routledge.

Leland, C., Lewison, M., \& Harste, J. (2013). Teaching children's literature: It's critical! New York, NY: Routledge.

Lewis, C., Enciso, P., \& Moje, E. (2007). Reframing sociocultural research on literacy: Identity, agency, and power. Mahwah, NJ: Lawrence Erlbaum. 
Martínez-Álvarez, P., \& Ghiso, M. P. (2014). Multilingual, multimodal compositions in technology-mediated hybrid spaces. In P. Fitzgerald (Ed.), Digital tools for writing instruction in K-12 settings (pp. 193-218). Hershey, PA: IGI Global.

Martínez-Roldán, C. M., \& Malave, G. (2004). Language ideologies mediating literacy and identity in bilingual contexts. Journal of Early Childhood Literacy, 4, 155-180.

McCaleb, S. P. (1994). Building communities of learners: A collaboration among teachers, students, families, and community. New York: St. Martin's Press.

Moll, L. C., Amanti, C., Neff, D., \& González, N. (1992). Funds of knowledge for teaching: Using a qualitative approach to connect homes and classrooms. Theory into Practice, 31, 132-141.

Parini, J. (2012). The American mythos. Daedalus, 141(1), 52-60.

Saldívar. J. (2011). Trans-americanity: Subaltern modernities, global coloniality, and the cultures of Greater Mexico. Durham, NC: Duke University Press.

Short, K. G., Kauffman, G., \& Kahn, L. H. (2000). "I just need to draw": Responding to literature across multiple sign systems. The Reading Teacher, 54, 160-171.

Siegel, M. (1995). More than words: The generative power of transmediation for learning. Canadian Journal of Education, 20, 455-475.

Siegel, M. (2006). Rereading the signs: Multimodal transformations in the field of literacy education. Language Arts, 84(1), 65.

Strauss, A., \& Corbin, J. (1998). Basics of qualitative research: Grounded theory procedures and techniques. Newbury Park, CA: Sage.

Street, B. V. (1995). Social literacies: Critical approaches to literacy in development, ethnography, and education. London, UK: Longman.

Van Leeuwen, T. (2004). Introducing social semiotics: An introductory textbook. London, UK: Routledge. 
Yair, G. (2009). Cinderellas and ugly ducklings: Positive turning points in students' educational careers - exploratory evidence and a future agenda. British Educational Research Journal, 35, 351-370.

Zacher Pandya, J. (2011). Overtested: How high-stakes accountability fails English Language Learners. New York, NY: Teachers College Press.

Zubizarreta, R. (1996). Transformative family literacy: Engaging in meaningful dialogue with Spanish-speaking parents. A training manual for Alma Flor Ada's Literatura Infantil y Familiar Program. Westlake, $\mathrm{OH}$ : Del Sol Publishing.

Patricia Martínez-Álvarez

Kolumbijos universitetas, Pedagogikos institutas, Jungtinès Amerikos Valstijos; pm2593@tc.columbia.edu

María Paula Ghiso

Kolumbijos universitetas, Pedagogikos institutas, Jungtinès Amerikos

Valstijos; ghiso@tc.edu

Gerald Campano

Pensilvanijos universitetas, Jungtinès Amerikos Valstijos;

campano@gse.upenn.edu

\section{DAUGIAMODALINIU TEKSTU PANAUDOJIMAS LOTYNU AMERIKOS KILMĖS DVIKALBIU AMERIKIEČIU KRITINIO POŽIŪRIO ‡̨ NEIŠSPRENDŽIAMAS DILEMAS UGDYMUI}

Santrauka. Šiame dvejus metus trukusiame kokybiniame tyrime dalyvavo 103 dvikalbiai pirmos klasès mokiniai, besimokantys pagal pradinès mokyklos raštingumo ugdymo programa, kurioje daug dèmesio skirta mokykloje ir už mokyklos ribu igytai patirčiai, fotografijai bei kitiems daugiamodaliniams tekstams kaip semiotiniams šaltiniams. Remdamiesi kritinès pedagogikos ir kultūros istorijos veiklu teorija, padejome moksleiviams kritiškai analizuoti dominuojančios hegemoninès perspektyvos epistemologines pasekmes. Vykdydami viena iš mokymosi programos užduočiu moksleiviai turejo fotografuoti savo kasdienes šeimos ir bendruomenès veiklas ir panaudoti šiuos vaizdus žodžiu pasakojant istorijas bei raštu kuriant daugiamodalinius produktus. Šiame straipsnyje analizuojame duomenu šaltinius - vaiku diskusiju mažose grupèse garso irašus ir ju daugiamodalinius tekstus. Atlikta teminè ir diskursinè duomenu analizè, nustatyti vaiku isitraukimo i veikla naudojant nuotraukas mokymosi procese modeliai. Tyrimas atskleidè, kad mokiniai užduoti atliko labai pilietiškai, atskleidè dažnai nutylimas socialines problemas ir bendruomenès skaudulius. Straipsnyje nagrinejjame moksleiviu dialogudiskusiju kulminacinius momentus, atveriančius galimybes aptarti temas, kuriu neretai išvengiama klasès kontekste; teigiame, kad iš tikruju toks pedagoginès erdvès panaudojimas gali padèti vaikams destabilizuoti istoriškai susiklosčiusias neišsprendžiamas dilemas, skatinančias tylos kultūrą. Pateikdami iliustruojančiu moksleiviu pokalbiu ir tekstu 
pavyzdžiu, nagrinejjame, kaip specifinis dèmesys mišriam žodiniam istoriju pasakojimo paskatintam dialogui, panaudojant technologijas, gali tapti kritinio tyrinejjimo platforma, kuri itraukia, bet ne nuslopina ar užgniaužia, su neišsprendžiamomis dilemomis susiduriantiems vaikams, atkreipiant dèmesi i ju imigracijos istorija, kultūrini bei kalbini identiteta.

Pagrindinès sąvokos: dvikalbis ugdymas, kritinis analizès metodas, kritinè pedagogika, švietimo technologijos, pradinis ugdymas, daugiamodalumas, antrosios kalbos. 